Abstract G121(P) Table 1 Results of data collection

\begin{tabular}{|c|c|c|c|c|c|c|}
\hline $\begin{array}{l}\text { Baby } \\
\text { Num }\end{array}$ & $\begin{array}{l}\text { Gender } \\
\text { Weight }\end{array}$ & $\begin{array}{l}\text { Antenatal } \\
\text { History }\end{array}$ & $\begin{array}{l}\text { Initial } \\
\text { FBC }\end{array}$ & $\begin{array}{l}\text { Initial } \\
\text { Clotting }\end{array}$ & $\begin{array}{l}\text { Age Blood } \\
\text { Products } \\
\text { Required } \\
1=20 \mathrm{mls} / \mathrm{kg}\end{array}$ & Outcome \\
\hline 1 & $\begin{array}{l}\text { Male } \\
4000 \mathrm{~g}\end{array}$ & $\begin{array}{l}\text { Born through thick meconium. Umbilicus } \\
\text { not clamped correctly with blood } \\
\text { loss (estimated } 50 \mathrm{mls} \text { ) from cord. } \\
\text { Required intubation and ventilation on } \\
\text { delivery suite. }\end{array}$ & $\begin{array}{l}\text { Hb15.8Plt } \\
179\end{array}$ & $\begin{array}{l}\text { PT } 27.8 \\
\text { INR } 2.8, \\
\text { APTT 29.4, } \\
\text { Fibr } 1.3\end{array}$ & $\begin{array}{l}40 \text { mins - } \\
1 \text { RBC } \\
6 \text { hrs - } 1 \text { FFP }\end{array}$ & $\begin{array}{l}\text { Meconium Aspiration required iNO and transfer } \\
\text { for ECMO. No further blood product support } \\
\text { required after initial correction. Discharged } \\
\text { home at } 6 \text { weeks old. }\end{array}$ \\
\hline 2 & $\begin{array}{l}\text { Female } \\
3460 \mathrm{~g}\end{array}$ & $\begin{array}{l}\text { Large antepartum haemorrhage due to vasa } \\
\text { previa. Fetal bradycardia so emergency } \\
\text { C-Section performed. Intubated and } \\
\text { ventilated on delivery suite. }\end{array}$ & $\begin{array}{l}\text { Hb13.1 } \\
\text { Plt } 66\end{array}$ & $\begin{array}{l}\text { PT } 49.4 \\
\text { INR } 5.5 \\
\text { APTT } 100.8 \\
\text { Fibr }<1.8\end{array}$ & $\begin{array}{l}7 \text { hrs }-1 \text { RBC } \\
11 \text { hrs }-2 \text { Plt } \\
13 \text { hrs - 1FFP }\end{array}$ & $\begin{array}{l}\text { Poor condition at birth secondary to fetal blood loss. } \\
\text { Fluid resuscitated with saline and blood. Clotting factors } \\
\text { given following abnormal results. Therapeutically cooled } \\
\text { and discharged home at } 3 \text { weeks of age. }\end{array}$ \\
\hline 3 & $\begin{array}{l}\text { Male } \\
3550 \mathrm{~g}\end{array}$ & $\begin{array}{l}\text { Fetal bradycardia following large APH. Delivered } \\
\text { following emergency C-Section. Required full } \\
\text { resuscitation with intubation, chest compressions, } \\
\text { adrenaline and emergency blood. }\end{array}$ & $\begin{array}{l}\text { Hb19.9 } \\
\text { Plt } 96\end{array}$ & $\begin{array}{l}\text { PT } 19.3 \\
\text { INR } 1.9 \\
\text { APTT } 41.1 \\
\text { Fibr } 1.2\end{array}$ & $\begin{array}{l}20 \text { mins - RBC } \\
8 \text { hrs - } 2 \text { FFP } \\
19 \text { hrs - } 1 \\
\text { Cryo, } \\
30 \text { hrs - Plt }\end{array}$ & $\begin{array}{l}\text { Severe coagulopathy requiring multiple corrections } \\
\text { over first } 4 \text { days of life. Transferred for surgical } \\
\text { care at } 6 \text { days of age due to bowel perforation. }\end{array}$ \\
\hline 4 & $\begin{array}{l}\text { Male } \\
2295 g\end{array}$ & $\begin{array}{l}\text { Cord snapped during delivery } \\
\text { in pool with unknown } \\
\text { volume of blood loss prior to manual clamping. } \\
\text { Responded to ventilation breaths but very pale } \\
\text { so transferred to NICU. }\end{array}$ & $\begin{array}{l}\text { Hb11.8 } \\
\text { Plt } 83\end{array}$ & $\begin{array}{l}\text { PT } 12.7 \\
\text { INR } 1.2 \\
\text { APTT } 28.4 \\
\text { Fibr } 1.3\end{array}$ & 9 hrs - RBC & Short admission for monitoring and transfusion. \\
\hline 5 & $\begin{array}{l}\text { Female } \\
3435 \mathrm{~g}\end{array}$ & $\begin{array}{l}\text { Born via Emergency C-Section for Antepartum } \\
\text { Haemorrhage and fetal bradycardia. Required full } \\
\text { resuscitation with intubation chest compressions, } \\
\text { emergency blood and adrenaline. }\end{array}$ & $\begin{array}{l}\text { Hb } 16.1 \mathrm{Plt} \\
110\end{array}$ & $\begin{array}{l}\text { PT } 20.3 \\
\text { INR } 2 \\
\text { APTT >135 } \\
\text { Fibr } 0.9\end{array}$ & $\begin{array}{l}20 \text { mins - RBC } \\
5 \text { hrs - RBC, } \\
\text { FFP and cryo } \\
12 \text { hrs - FFP }\end{array}$ & $\begin{array}{l}\text { Deteriorated from day } 2 \text { of life with widespread } \\
\text { organ dysfunction and bradycardias. Reorientation } \\
\text { of care, sadly passed away on day } 3 \text { of life. }\end{array}$ \\
\hline 6 & $\begin{array}{l}\text { Female } \\
3748 \mathrm{~g}\end{array}$ & $\begin{array}{l}\text { Emergency C-Section following failed forceps } \\
\text { delivery. Born with poor perfusion and noted } \\
\text { to have large subgalial bleed. }\end{array}$ & $\begin{array}{l}\text { Hb } 13.0 \text { Plt } \\
249\end{array}$ & $\begin{array}{l}\text { Clotting } \\
\text { Screen } \\
\text { not Performed }\end{array}$ & $\begin{array}{l}1 \mathrm{hr}-\mathrm{RBC} \\
14 \mathrm{hrs}-\mathrm{RBC}\end{array}$ & $\begin{array}{l}\text { Stabilised following transfusion required short stay } \\
\text { for monitoring of OFC and establishing feeds. }\end{array}$ \\
\hline 7 & $\begin{array}{l}\text { Female } \\
3680 \mathrm{~g}\end{array}$ & $\begin{array}{l}\text { Artificial rupture of membranes - frank blood. } \\
\text { Fetal bradycardia then lost heart rate prior to } \\
\text { emergency C-Section. Required extensive } \\
\text { resuscitation at delivery, first heart rate at } 17 \\
\text { mins }\end{array}$ & $\begin{array}{l}\text { Hb } 122 \\
\text { Plt } 108\end{array}$ & $\begin{array}{l}\text { PT } 17 \\
\text { INR } 1.6 \\
\text { APTT } 123.1 \\
\text { Fibr } 1.0\end{array}$ & $\begin{array}{l}25 \text { mins - RBC. } \\
7 \mathrm{hrs}-\mathrm{FFP} \\
18 \mathrm{hrs}-2 \times \\
\text { RBC } \\
20 \mathrm{hrs}-\text { CRYO. }\end{array}$ & $\begin{array}{l}\text { Severe HIE, multiorgan failure. Transferred to PICU } \\
\text { for dialysis and laparotomy due to intestinal } \\
\text { perforation. }\end{array}$ \\
\hline
\end{tabular}

$91 \%$ of responders would always offer intensive care with the intention of admitting to NICU at 25 weeks gestation and above, compared to $58 \%$ at 24 weeks and $6.8 \%$ at 23 weeks gestation. At 24 weeks, $38 \%$ of responders would make the decision of whether to resuscitate based on the infant's initial clinical condition compared to $61 \%$ at 23 weeks. For 23 weeks gestation infants, giving precedence to parents' wishes (57\%) and weighing the baby before commencing resuscitation (32\%) were highest. At 22 weeks, $58 \%$ of responders would not resuscitate and $29 \%$ would not attend the delivery.

Conclusion There were varied responses at every gestation. Whilst the majority of 25 week and above gestation infants are offered full intensive care in accordance with Nuffield guidance, this was not the case for 24 week gestation infants. Initial clinical condition and response to initial resuscitation at birth play a larger role in decision making at 23 and 24 weeks. Parents' wishes and birthweight are more significant factors in decision making at 23 weeks. The varying attitudes to practice at each gestation highlight the challenges in following guidelines in the resuscitation of extreme preterm infants. This calls into question whether there is a need for more consensus.

\section{G124(P) IS IT TIME TO ENFORCE RIGOROUS INFECTION CONTROL GUIDELINES FOR VISITORS ATTENDING THE NEONATAL INTENSIVE CARE UNIT?}

H Yaseen, H Yaseen, U El-Kafrawy. Neonatal Intensive Care Unit, Bolton NHS Foundation Trust, Bolton, UK

\subsection{6/archdischild-2015-308599.123}

Nosocomial infections remain a major issue in neonatal intensive care units (NICU). This is related to numerous factors including, impaired immunity, fragile skin, and invasive lines. The impact of healthcare workers on infection transmission has been well documented, however little work has looked at the risk posed by visitors who frequently handle infants on NICU. 
Aims The aim of our study was to assess the existing infection control guidelines and their enforcement for visitors attending tertiary level NICUs across England and to recommend a standard set of guidelines to reduce the risk of infection in infants on NICU.

Methods Our study included 46 level 3 NICUs across England during November 2013-March 2014. A survey questionnaire was set and the sister in charge was contacted by telephone.

Results Among 46 units, 46(100\%) responded to the survey. 27 $(58.7 \%)$ provided infection control leaflets for visitors, all of those included hand washing. 15 of the $27(55.5 \%)$ had multilingual leaflets. $34(73.9 \%)$ used a cot-side nurse or receptionist to enforce infection control policies. 11(23.9\%) had no restricted visiting times, only if accompanied by parents. 42(91.3\%) allowed siblings, however 2 excluded winter, 1 disallowed siblings under 6, and 1 only in infectious outbreaks. 26 (56.5\%) had a limited handling policy. All allowed kangaroo care, 28 $(60.9 \%)$ of which stipulated only when the baby was stable. 10 $(21.7 \%)$ allowed it any time. $1(2.2 \%)$ only permitted on extubation and if lines were taken out. 42(91.3\%) prohibited wearing coats. $3(6.5 \%)$ had a bare below the elbow policy and 25 $(54.3 \%)$ asked that jewellery was removed. None of the units asked visitors to remove plain bands. All stipulated hand washing, however 44(95.6\%) stipulated hand gelling. 3(6.5\%) stipulated the wearing of gowns, and 4 (8.6\%) asked visitors to wear gloves, both of which were only necessary if the baby had an infection.

Conclusion Our study results have thrown light on variations in infection control policies for visitors to NICUs across England. A set of infection control guidelines and methods for their enforcement are proposed.

\section{G125(P) UK TRANSFUSION-ASSOCIATED NECROTISING ENTEROCOLITIS CASES IDENTIFIED THROUGH A MULTICENTRE AUDIT}

${ }^{1} \mathrm{~S}$ Hamad, ${ }^{2} \mathrm{~K}$ Jones, ${ }^{3} \mathrm{~K}$ Sim, ${ }^{4} \mathrm{~S}$ Cherian, ${ }^{5} \mathrm{~A}$ James, ${ }^{2} \mathrm{~S}$ Godambe, ${ }^{6} \mathrm{H}$ New, ${ }^{3} \mathrm{SS}$ Kroll, ${ }^{1} \mathrm{P}$ Clarke. ${ }^{1}$ Neonatal Unit, Norfolk and Norwich University Hospitals NHS Foundation Trust, Norwich, UK; ${ }^{2}$ Neonatal Unit, Imperial College Healthcare NHS Trust, London, UK; ${ }^{3}$ Department of Medicine, Section of Paediatrics, Imperial College, London, UK; ${ }^{4}$ Neonatal Unit, University Hospital of Wales, Cardiff, UK; ${ }^{5}$ Neonatal Unit, Royal Gwent Hospital, Newport, UK; ${ }^{6}$ Department of Paediatrics, Imperial College Healthcare NHS Trust/NHS Blood and Transplant, London, UK

\subsection{6/archdischild-2015-308599.124}

Aim Transfusion-associated necrotising enterocolitis (TANEC) has been reported from The Americas and various European countries at rates comprising $27-38 \%$ of necrotising enterocolitis (NEC) cases. While the role of packed red blood cell (PRBC) transfusion in causation of NEC remains debated, there are surprisingly few reports of TANEC in the UK setting. Our aim was to analyse the incidence of NEC and TANEC in UK NICUs using uniform definitions.

Methods We undertook a retrospective multicentre audit covering the period October 2011 to November 2014 in four tertiary-level UK NICUs. We assessed whether definite NEC cases (NEC diagnosed surgically via laparotomy, post-mortem, and/or a strict clinical-radiological diagnosis) were also TANEC cases (first onset of NEC symptoms within $48 \mathrm{~h}$ of commencement of a PRBC transfusion). Of participating NICUs, three introduced routine probiotic prophylaxis during the study period and one practised routine cessation of enteral feeding during PRBC transfusions.
Results 1608 (20.1\%) of 8007 babies admitted in the 38-month study period were very low birth weight (VLBW) and 68 (4.2\%) had definite NEC. Of these $15(22.1 \%)$ were TANEC; 34 (50.0\%) had received prior PRBC transfusion but were not TANEC; 19 (27.9\%) had received no prior PRBC transfusion. Across NICUs, the incidence of definite NEC ranged from 4.5-9.7 cases/year (3.6-7.8 per 100 VLWB admissions) and that of TANEC ranged from $0.50-1.95$ cases/year $(0.4-1.7$ per 100 VLWB admissions). The proportion of TANEC/NEC cases within individual NICUs ranged from 11\%-40\%. TANEC cases were of median birth weight $695 \mathrm{~g}$ (range: 527-1070 g) and birth gestation $25^{+1}$ weeks (range: $23^{+2}-27^{+0}$ weeks). Median age at start of the index PRBC transfusion was 18 days (range: 0-69 days). Overall, $12(80 \%)$ required surgical intervention and $9(60 \%)$ survived to discharge. Four (27\%) TANEC cases occurred in babies who had received prior probiotics.

Conclusion TANEC occurs in the UK in proximal association with PRBC transfusion at rates similar to those reported from other countries. Rates of NEC and TANEC vary widely between UK centres. A large prospective UK surveillance study is now indicated to improve the understanding of the causation of TANEC.

\section{G126(P) AN AUDIT ON HOME NASOGASTRIC TUBE FEEDING PRACTICES IN A REGIONAL NEONATAL UNIT}

${ }^{1} \mathrm{~N}$ Athiraman, ${ }^{2} \mathrm{R}$ Coombs, ${ }^{2} \mathrm{~J}$ Paulucy, ${ }^{2} \mathrm{D}$ Crossley, ${ }^{2} \mathrm{~J}$ Shaw. ${ }^{1}$ The Newcastle Upon Tyne Hospitals NHS Foundation Trust, Newcastle-Upon-Tyne, UK; ${ }^{2}$ Sheffield Teaching Hospitals NHS Foundation Trust, Sheffield, UK

\subsection{6/archdischild-2015-308599.125}

Introduction Infants who are borderline premature, low birthweight and multiple births have extended stay within the neonatal unit, primarily to establish feeds. Discharging these infants' home on nasogastric feeds (NGF) to establish feeds, would have significant benefits for family bonding and freeing neonatal cot spaces. However, there is a need for risk assessment as well as parental training. Aim To identify the benefits and safety of nasogastric feeding at home.

The objective is to identify the number of saved bed days and costs, infants' growth and support required at home

Methods This audit was conducted over a period of 18 months from January 2011 to June 2012. All the infants discharged home on NGF were identified from the community database and data collected from medical as well as community nursing notes. Two days were added to the total, as the unit protocol is to observe infants for $48 \mathrm{hrs}$ after fully established feeds, before discharging home.

Abstract G126(P) Table 1 Home NG feeding after early discharge, and their outcomes

\begin{tabular}{ll}
\hline Characteristic & $\mathrm{N}=30$ \\
\hline Sex & Male: $17(56.7 \%)$ \\
Gestational age at birth & Median: 33.1 weeks \\
Gestational age at discharge & Median: 36.4 weeks \\
Gestational age at end of NG feeding & Median: 37 weeks \\
& Median: 8 days \\
No. of days NG fed at home & Range: $2-24$ days \\
Birth weight & Median: $1.94 \mathrm{~kg}$ \\
Discharge weight & Median: $2.18 \mathrm{~kg}$ \\
Weight at end of NG feeding & Median: $2.22 \mathrm{~kg}$ \\
Type of feeding & Breast: $18(60 \%)$ \\
\hline
\end{tabular}

